\title{
Influence of digital technologies on higher education students in times of the Covid- 19 pandemic and the repercussions on their study habits
}

\section{Influencia de las tecnologías digitales en los estudiantes de educación superior en tiempos de pandemia del Covid-19 y las repercusiones en sus hábitos de estudio}

\author{
MIRELES-MEDINA, Antonia $\dagger^{*}$, MOLINA-WONG, Ma. del Refugio, ÁBILA-AGUILAR, Verenice \\ and MOTA-GARCÍA, María Juana
}

Instituto Tecnológico Superior Zacatecas Norte

Tecnológico Nacional de México, Campus Zacatecas Norte

ID $1^{\text {st }}$ Author: Antonia, Mireles-Medina / ORC ID: 0000-0001-9773-9108, CVU CONACYT ID: 299436

ID $1^{\text {st }}$ Co-author: Ma. del Refugio, Molina-Wong / ORC ID: 0000-0002-4935-6994, CVU CONACYT ID: 998827

ID $2^{\text {nd }}$ Co-author: Verenice, Ábila-Aguilar / ORC ID: 0000-0003-1530-7622, CVU CONACYT ID: 975536

ID $3^{\text {rd }}$ Co-author: María Juana, Mota-García / ORC ID: 0000-0003-1127-1116, CVU CONACYT ID: 636080

DOI: $10.35429 / J I T C .2021 .13 .5 .1 .8$

Received March 10, 2021; Accepted June 30, 2021

\begin{abstract}
In this article, a second analysis is carried out that consists of monitoring the study habits of a group of 17 students, during the period of their higher education. The study was carried out on students who correspond to the area of Computational Sciences and consists of making a comparative evaluation of the application of the study habits questionnaire to such a group of students in four moments of their career path. In the first, second and third moments, the students attended classes in a face-to-face modality and in the fourth moment the students attended due to COVID-19 pandemic situations in a virtual modality. Based on the second context, the analysis has been carried out. The interest in delving into study habits is to identify areas of opportunity and implement strategies that allow students to improve them and avoid vices that hinder enough to obtain better academic performance.
\end{abstract}

Information and Communication Technologies, Study habits, Virtual modality

\begin{abstract}
Resumen
En este artículo se realiza un segundo análisis que consiste en el seguimiento de los hábitos de estudio a un grupo de 17 estudiantes de sexto semestre, durante el periodo de su educación a nivel superior. El estudio se realizó a estudiantes que corresponden al área de las Ciencias Computacionales y consiste en hacer una evaluación comparativa de la aplicación del cuestionario de hábitos de estudio a tal grupo de estudiantes en cuatro momentos del recorrido de su carrera. En el primero, segundo y tercer momento los estudiantes asistieron a clases en una modalidad presencial y en el cuarto momento los estudiantes asistieron por situaciones de pandemia del COVID-19 en una modalidad virtual. En base al segundo contexto es que se ha llevado a cabo el análisis. El interés por ahondar en los hábitos de estudio es para identificar áreas de oportunidad e implementar estrategias que permitan a los estudiantes mejorarlos y evitar vicios que entorpecen que estos sean los suficientes para obtener un mejor rendimiento académico.
\end{abstract}

Tecnologías de la Información y Comunicación, Hábitos de estudio, Modalidad virtual

\footnotetext{
* Correspondence to Author (e-mail: mirelesmed_7@ @otmail.com)

$\dagger$ Researcher contributing as first author
} 


\section{Introduction}

COVID-19 has struck our education system like lightning and shaken it to the bottom. (Kandri, 2020). Without a doubt in our Mexican country has not been the exception of such a situation that has led him to consider new strategies to bring education to his students. The World Health Organization (OMS) defines COVID-19 as a disease caused by the novel coronavirus known as SARS-CoV-2. OMS first became aware of the existence of this new virus on 31 December 2019, when it was informed of a group of cases of "viral pneumonia" that had been declared in Wuhan (People's Republic of China) (OMS, 2020).

On 11 March 2020, the OMS declared the COVID-19 epidemic a pandemic (OMS, 2020a), which currently affects countries around the world. The global COVID-19 crisis has affected education systems around the world, including institutions of higher education (IES), as most of them have been forced to close their facilities and temporarily suspend on-campus learning. (UNESCO, 2020). Given the situation declared by the OMS, Mexico also interrupted the face-to-face interaction of the school system at the higher education level. (México. Diario Oficial de la Federación, 2020).

The Ministry of Public Education in coordination with the National Council of Educational Authorities (CONAEDU) and in collaboration with the Ministry of Health as part of the provisions of the education sector in the face of the coronavirus (COVID-19) carried out the suspension of face-to-face classes on March 20, 2020 (SEP, 2020a).

The National Education System contributed to the temporary suspension of activities of 40.7 million people who study and work in all types and levels of education, equivalent to $32.3 \%$ of the national population. On the other hand, the IES also contributed to the temporary suspension of activities of 5.3 million people, which is equivalent to $4.2 \%$ of the national population (SEP, 2020b).

According to UNESCO (2020), IES have a crucial role to play in ensuring that the right to quality education and learning opportunities for all is not compromised by the COVID-19 pandemic.
In the case of higher education in Mexico, certain entities issued documents as suggestions, such as the National Association of Universities and Institutions of Higher Education (2020). In the context of the global health contingency caused by COVID-19, public and private institutions of higher education and public research centers, associated with ANUIES, reiterate their commitment to safeguarding the health of their communities and society in general; ensure the continuity of their academic services; make available to society its scientific and technical capabilities, and if necessary, its infrastructure and equipment to address the effects of this epidemiological phenomenon (ANUIES, 2020).

COVID-19 shows us that continuity of education must be ensured and UNESCO is committed to supporting governments in distance education, open science and the exchange of knowledge and culture (UNESCO, 2021). The closure of educational centers and the replacement of face-to-face classes by on-line and distance training has no alternative, due to the situation we are facing with a health crisis. So there is no other possible way out than to close schools and replace face-to-face classes with online training (SANZ, 2020).

According to data from UNESCO (2020c), more than $90 \%$ of the world's population has had to continue their educational processes from home, learning remotely and implementing at the same time different learning platforms.

\section{Problem}

Currently, the way classes are taught in educational institutions has changed dramatically, this stemming from the COVID-19 pandemic; in a sudden way and without expecting such a situation the schools of higher education have seen the need to change their didactic planning to adapt them from a face-toface modality to a virtual modality. Inaddition, to look for strategies that encourage students to study habits. Based on this, a series of questions have arisen such as: How do digital technologies influence higher education students in times of the COVID-19 pandemic?, what are the repercussions on their study habits of students when implementing Information and Communication Technologies (ICT)?, howhave study habits beenstrengthenedin the virtual modality?,

MIRELES-MEDINA, Antonia, MOLINA-WONG, Ma. del Refugio, ÁBILAAGUILAR, Verenice and MOTA-GARCÍA, María Juana. Influence of digital technologies on higher education students in times of the Covid-19 pandemic and the repercus on their sty hits. Journt of Infortic 
Will study habits have increased by implementing a virtual modality to meet the needs of the teaching-learning process in students? How has the behavior of study habits been throughout the career of students belonging to the area of Computational Sciences?

\section{General objective}

Analyze the study habits in 17 sixth semester students of Computer Systems Engineering of the Tecnológico Nacional de México, Campus Zacatecas Norte through a comparative study taking into account four periods, where the first, second and third correspond to the study habits implemented by the students in a face-to-face modality and the fourth moment in a virtual modality derived from the pandemic situation generated by COVID-19.

\section{Specific objectives}

1. Apply the questionnaire of study habits of José Luis Díaz Vega to the students of the area of the Computational Sciences of the Tecnológico Nacional de México, Campus Zacatecas Norte.

2. Capture and interpret the results obtained from the data collection instrument applied to students in the area of Computational Sciences of the Tecnológico Nacional de México, Campus Zacatecas Norte.

3. To present a comparative analysis of the results obtained in the four periods studied in the students of the area of Computational Sciences of the Tecnológico Nacional de México, Campus Zacatecas Norte, Campus Zacatecas Norte.

\section{Reference framework}

\section{TCI in education in a virtual modality}

Information and communication technologies (ICT) have now provided adequate tools to support the teaching-learning process so that they have been used in both the presencel and virtual modality. "Both in the face-to-face and in the virtual modality the purpose is the construction of knowledge by the students" (Manzuoli \& Escofet Roig, 2015).
"Virtual education is a learning modality that has grown rapidly in practice, but still, it is pending the dissemination of the way in which the educational process is managed" (Toledo, Correa Castillo, Valdés Montecinos, \& Hadweh Briceño, 2020).

For García Aretio (2002), distance education "is a technological system of two-way (multidirectional) communication, which can be massive, based on the systematic and joint action of didactic resources and the support of an organization and tutoring that, physically separated from the students, promote in them an independent (cooperative)learning".

Aliste (2006) says that distance education is "the combination of education and communication technologies to reach an audience interested in learning that is separated by great distances".

Torres (2004) considers it as: "a set of pedagogical strategies and communication mechanisms that link tutor teachers with students to develop teaching and learning activities, not coinciding in time and geographical space, developing, in general, outside university campuses".

While Burns (2011) defines it as a planned learning experience characterized by the separation between the student and the teacher, whose separation is compensated by the exchange of information and communication through print and electronic media.

The terms or expressions that have been used to refer to network learning have been different: network learning, teletraining, elearning, virtual learning, etc. By all of them we generally refer to the training that uses the network as a technology for the distribution of information, whether this network is open (Internet) or closed (intranet) (Almenara, 2006).

With the use of new information and communication technologies, information reaches anywhere in the world in seconds. Through networks, science reaches everyone. Current conditions require new means to facilitate the mass transmission of the teacher's knowledge to students and their assimilation by them. Technologies act as intermediaries in this process, without their mediation it is impossible to create a broad and effective education system (Sanchez \& R, 2003).

MIRELES-MEDINA, Antonia, MOLINA-WONG, Ma. del Refugio, ÁBILAAGUILAR, Verenice and MOTA-GARCÍA, María Juana. Influence of digital technologies on higher education students in times of the Covid-19 pandemic and technologies on higher education students in times of the Covid-19 pandemic and
the repercussions on their study habits. Journal of Information Technologies and the repercussions on their study habits. Journal of Information Technologies and 


\section{Use of ICts in education in times of COVID- 19 pandemic}

"Quarantine, in short, has accelerated by great strides the use of ICT for almost all daily activities, forcing users to use smart mobile devices connected to the network to perform any daily work" (Reinoso, 2020). Likewise, (Abitia, 2021) considers that the COVID-19 pandemic has accelerated the use of digital technologies for 10 years, given that in 2000 there was 5.1 percent penetration of ICT; a decade later it went to 31 percent; in 2015, to 57.4 percent, and at the moment we are at more than 70 percent. "Chances are we'll have near-total coverage in the next two years."

UNESCO produced a list of applications, platforms and resources for education with the aim of helping parents, teachers, schools and administrators to facilitate student learning and provide care and social interaction during school closures. Most of the selected solutions are free and many are adapted to multiple languages, classified according to distance learning needs (UNESCO, 2020b).

For its part, the TECNM (2021) also recommends some educational technologies. Based on this, the Tecnológico Nacional de México, Campus Zacatecas Norte homologized the use of technologies for virtual classes, so Zoom was chosen for video calls or videoconferences, Moodle as an LMS platform, as well as the use of email and Whatsapp as additional technologies and for other communication scenarios. It was decided to use the Moodle LMS platform because it is chosen by higher education institutions around the world, being used by more than $60 \%$ of all higher education in the world. Among the most popular uses are online exams, active learning (forums, wikis), online grading, etc. (Moodle, 2020).

Zoom is a Cloud Platform for video and audio conferencing, collaboration, chat and webinars (UNESCO, 2020b) Kandri (2020), in its article expresses that each level of education faces its unique challenges, it is the segment of higher education that can end up, by necessity, triggering a learning revolution. Universities are distinctive in the point that their students are old enough to handle the rigors of online work and technologically intelligent enough to navigate new platforms.
(Lloyd, 2020)mentions that the COVID19 pandemic has exacerbated the already wellknown educational discrepancies in Mexico and other countries. He also says that despite the need to cancel face-to-face classes due to the virus, the Mexican government and educational institutions have helped with a variety of technologies in an attempt to continue providing education to more than 36 million children and adults in the country. However, the new virtual offer faces limitations, difficulties and ethical questions, especially in terms of the fairness of the model.

\section{Study habits(SH)}

"The habit of study are constant modes of action with which the student reacts to new contents, to know them, understand them and apply them. We can list, as the most important the following: take advantage of the study time, achieve ideal conditions, discard the disturbing elements, effectively raise the work, correctly select the sources of information and documentation, properly present the results, master the techniques of observation, attention, concentration and relaxation" (Sánchez, 2002).

Habit requires three elements to put it into action: a) knowledge, b) abilities and c) desire (Covey, 2009). The habits that a student has can be lost, but they can also be increased or recovered (Díaz and García, 2008). Authors such as Bajwa, Gujjar, Shaheen and Ramzan (2011) mention that a student cannot use effective study skills until they have good habits and argue that an individual learns more quickly and deeply than others because of their successful study habits.

Escalante (2005), mentions that the success or failure of our studies depend largely on study habits, which are formed by the following variables: Hygiene strategies, Material conditions and Study strategies. As they state (Gutiérrez, Pacheco Amigo, \& Rodríguez García, 2017) "Study habits are the right means to achieve the conditions for a better education".

(Gutiérrez, Pacheco Amigo, \& Rodríguez García, 2017) quoting Aula Santillana consider that "Study habits are the constant modes of action with which the student reacts to new contents, to know them, understand them and apply them". 
For the purposes of this analysis, the questionnaire proposed by (Díaz Vega, 2006) has been considered as a data collection instrument, which considers seven variables or factors such as: Time Distribution (TD), Motivation towards the Study (MtS), Distractors in the Study (DS), Class Notes (CN), Reading Optimization (RO), Exam Preparation (EP), and Attitude towards Study (AtS).

\section{Methodology}

The research that is proposed has the following characteristics: it is descriptive, it has a quantitative approach, with a non-experimental design, merely longitudinal (Sampieri,Collado Fernández, \& Baptista Lucio, 2014), derived from the fact that a statistical analysis of study habits is presented in four periods respectively, in a sample of 17 students of Computer Systems Engineering of the National Tecnological of Mexico, Campus Zacatecas Norte , that is, data from the first, second, fourth and sixth semester have been collected by means of a questionnaire of the author (Díaz Vega, 2006), which considers seven variables or factors such as: Time Distribution (TD), Motivation towards the Study motivation in the study (MtS), Distractors in the Study (DS), Class Notes (CN), Reading Optimization (RO), Test Preparation (EP), and Attitude toward Study (AtS).

It is important to mention that this article takes into account the same objects of study to which the following authors refer in their research (Medina, Arredondo Salcedo, Castañeda Delgado, \& Mota García, 2020), in order to monitor the behavior of the study habits that students have presented in the modalities: face-to-face and virtual. Once the data have been obtained, statistical techniques have been used and interpreted for analysis in order to understand the situation with respect to the study habits that students practice. To later, inquire about the repercussions on study habits by the use of technologies in classes in a virtual modality.

\section{Results}

It is necessary to consider in this section the weighting of the study habits that are made up of the points and percentages that are acquired once the data collection instrument proposed by the author has been answered (Díaz Vega, 2006).
As shown in Table 1 cabe highlight that a score greater than or equal to $21(70 \%)$, is the acceptable score, however, it can be further reinforced through the implementation of appropriate didactic strategies. The weights shown are those that the author mentioned above considers to measure the study habits in students:

\begin{tabular}{|r|r|}
\hline \multicolumn{2}{|c|}{ Weightings } \\
\hline Points & Percentage \% \\
\hline 30 & $100 \%$ \\
\hline 27 & $90 \%$ \\
\hline 24 & $80 \%$ \\
\hline 21 & $70 \%$ \\
\hline 18 & $60 \%$ \\
\hline 15 & $50 \%$ \\
\hline 12 & $40 \%$ \\
\hline 9 & $30 \%$ \\
\hline 6 & $20 \%$ \\
\hline 3 & $10 \%$ \\
\hline
\end{tabular}

Table 1 Weighting in points and percentages Source: Own Elaboration, (2021)

Table 2 shows the variation in study habits based on the average that has been acquired as a group in the four semesters:

\begin{tabular}{|l|r|r|r|r|}
\multicolumn{6}{|c|}{ Average in percentage per semester } \\
\hline SH & First & Second & Fourth & Sixth \\
\hline TD & 42 & 32 & 37 & 42 \\
\hline MtS & 70 & 64 & 69 & 67 \\
\hline DS & 50 & 42 & 48 & 48 \\
\hline CN & 63 & 59 & 65 & 57 \\
\hline RO & 49 & 39 & 49 & 49 \\
\hline EP & 64 & 61 & 63 & 67 \\
\hline AtS & 64 & 57 & 60 & 63 \\
\hline
\end{tabular}

Table 2 Average as a percentage per semester of the $\mathrm{SH}$ Source: Own elaboration, (2021)

The data in the table above are shown in Graphic 1, in which it can be identified that in five of the seven variables are maintained or there is an increase in the percentage of SH. In the variables DS and RO there is no change; however in TD, EP and AtS show an increase.

It should be noted that the students in the sixth semester were forced to venture and adapt to a virtual modality, due to the pandemic situation, which is the world stage in the education, with this pausing the face-to-face classes; so it is reflected in the variables MtS and $\mathrm{CN}$ with a downward change. 


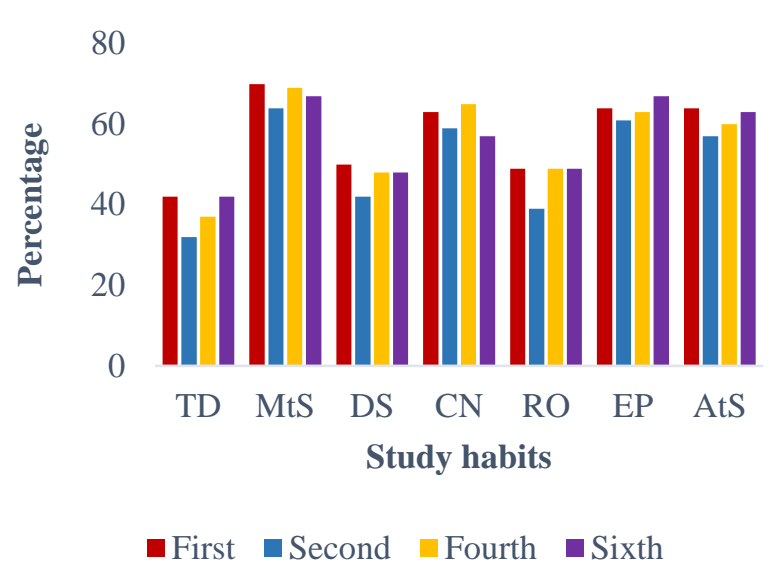

Graphic 1 Group average of SH in \%

Source: Own Elaboration, (2021)

Another statistical technique that has been used for the treatment of the data in this article is the standard deviation Table 3:

\begin{tabular}{|l|r|r|r|r|}
\hline \multicolumn{6}{|c|}{ Average in percentage per semester } \\
\hline SH & First & Second & Fourth & Sixth \\
\hline TD & 12 & 10 & 12 & 13 \\
\hline MtS & 10 & 10 & 11 & 20 \\
\hline DS & 10 & 15 & 11 & 14 \\
\hline CN & 11 & 14 & 12 & 17 \\
\hline RO & 14 & 16 & 12 & 15 \\
\hline EP & 8 & 13 & 13 & 20 \\
\hline AtS & 9 & 9 & 9 & 19 \\
\hline
\end{tabular}

Table 3 Group standard deviation of the SH Source: Own Elaboration, (2021)

Graphic 2 shows the behavior of the standard deviation of the study habits of the 17 students of Computer Systems Engineering of the Tecnológico Nacional de México, Campus Zacatecas Norte, in order to see how dispersed the data are with respect to the mean. By which a greater variability or dispersion can be seen in some data which indicates a certain heterogeneity in some study habits:

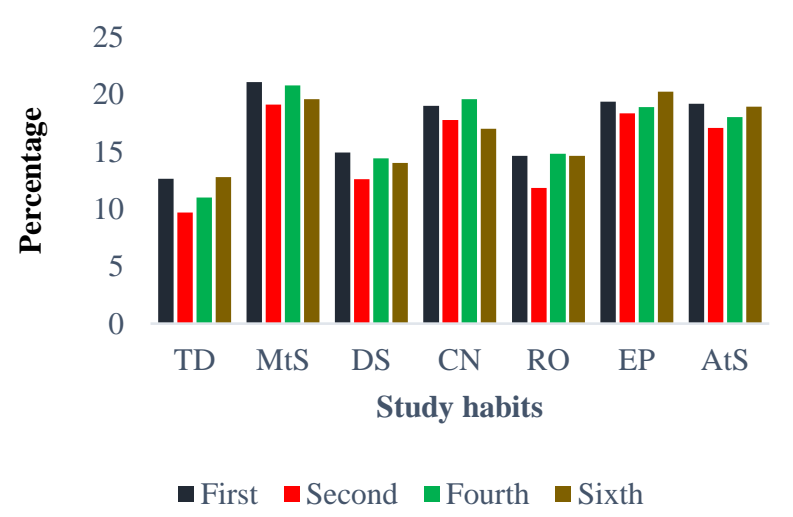

Graphic 2 Percentage of group standard deviation of SH per semester

Source: Own Elaboration, (2021)

\section{Acknowledgment}

Our acknowledgment to the Tecnológico Nacional de México, Campus Zacatecas Norte (Instituto Tecnológico Superior Zacatecas Norte) for the support provided to carry out this research.

\section{Conclusions}

Facing the great challenge of classes in a virtual modality involves teamwork on the part of higher education institutions, as well as constant monitoring in the promotion of study habits in students, to generate strategies that allow positively favoring the customs they implement to acquire constant learning.

As can be seen from the results, the impact of the COVID-19 pandemic on conducting classes differently from how students were used to has affected their study habits to some extent, so that there is no significant increase, rather in some of them there is a considerable decrease.

It should be noted that in the study habits where there was a decrease in the period where the virtual modality has been implemented due to the COVID-19 pandemic are: motivation to study $(\mathrm{MtS})$ and class grades $(\mathrm{CN})$.

For the above mentioned, it is necessary as future work to carry out a study where the causes and consequences that affect so that the study habits in students are not consolidated as techniques used in their continuous learning process are identified.

\section{References}

Abitia, G. R. (16 de mayo de 2021). Dirección General de Comunicación Social. Obtenido de https://www.dgcs.unam.mx/boletin/bdboletin/2 021_419.html

Aliste Fuentes, C. (2006). Modelo de comunicación para la enseñanza a distancia en internet. (Tesis doctoral). Universidad Autónoma de Barcelona.

Almenara, J. C. (2006). Bases pedagógicas del e-learning. RUSC. Universities and knowledge society journal, 3(1), 0 . 
ANUIES. (2020). Acuerdo Nacional por la Unidad en la Educación Superior frente a la emergencia sanitaria provocada por el COVID19 Consejo Nacional de la ANUIES. Abril, 24, 1-2. Disponible en: http://www.anuies.mx/media/docs/avisos/pdf/2 00424155500Acuerdo+Nacional+frente+al+CO VID-19.pdf

Asociación Nacional de Universidades e Instituciones de Educación Superior. (2020). Sugerencias para mantener los servicios educativos curriculares durante la etapa de emergencia sanitaria provocada por el COVID19. ANUIES. Disponible en: http://www.anuies.mx/media/docs/avisos/pdf/2 00417111353Sugerencias+para+mantener+los+ servicios+educativos.pdf

Bajwa, N., Gujjar, A., Shaheen, G., y Ramzan, M. (2011). A comparative study of the study habits of the students from formal and nonformal systems of education in Pakistan. International Journal of Business \& Social Science, 2(14), consulted of E-Journal database. pp. 175-186, http://www.scielo.org.mx/scielo.php?script=sci nlinks\&ref $=5159708 \&$ pid $=$ S0185-

$2760201200030000300004 \& \operatorname{lng}=\mathrm{es}$

Burns, M. (2011). Distance Education for Teacher Training: Modes, Models and Methods. Washington: Education Development Center. Disponible en: http://idd.edc.org/sites/idd.edc.org/files/Distanc e\%20Education\%20for\%20Teacher\%20Trainin g\%20by\%20Mary\%20Burns\%20EDC.pdf

Covey, S. (2009). Los siete hábitos de la gente altamente efectiva. Barcelona. ed. Paidós

Díaz, S. y García M. (2008). Escuela de desarrollo de hábitos. Vencer las rutinas para conseguir hábitos directivos saludables. $2^{\mathrm{a}}$ ed. Madrid. ed. Díaz de Santos.

Díaz Vega, J. L. (2006). Aprende a estudiar con éxito (1a. ed.). Ciudad de México, México: Trillas.

Escalante-Estrada, Luis E. (2005). Apuntes del curso El Proceso Educativo. Cocula, Guerrero. México: Centro de Estudios Profesionales, dependiente del Colegio Superior Agropecuario del Estado de Guerrero.
García Aretio, L. (2002). La educación a distancia: de la teoría a la práctica.

Gutiérrez, J. L., Pacheco Amigo, B. M., \& Rodríguez García, F. J. (2017). Formación de hábitos de estudio: Comparación entre alumnos de secundaria y alumnos universitarios. Revista de Docencia e Investigación Educativa, 3(8), 5563.

Kandri, S. (2020). How COVID-19 is driving a long-overdue revolution in education. (Cómo COVID-19 está impulsando una revolución largamente esperada en la educación) World Economic Forum [en línea] Disponible en: https://www.weforum.org/agenda/2020/05/how -covid-19-is-sparking-a-revolution-in-highereducation/ [Consultado el 12 de junio de 2020]

Lloyd, M. (2020). Desigualdades educativas y la brecha digital. Educación y pandemia; Creative Commons ReconocimientoNoComercialSinObraDerivada 4.0 Internacional (CC BY-NC-ND 4.0), 115-121. Obtenido de http://132.248.192.241:8080/jspui/bitstream/IIS UE_UNAM/546/1/LloydM_2020_Desigualdad es_educativas.pdf

México. Diario Oficial de la Federación (2020). Acuerdo número 02/03/20. https://www.dof.gob.mx/nota detalle.php? codigo $=5589479 \&$ fecha $=16 / 03 / 202$ 0 .

Manzuoli, C. H., \& Escofet Roig, A. (2015). Construcción de conocimiento en educación virtual: Nuevos roles, nuevos cambios. RED Revista de Educación a Distancia (45). Obtenido de

https://revistas.um.es/red/article/view/238611

Medina, A. M., Arredondo Salcedo, D., Castañeda Delgado, J., \& Mota García, M. (2020). Análisis de los hábitos de estudio en estudiantes de nivel superior, un caso de estudio. Revista de Educación Superior, 4(11), 1-10.

Moodle (2020). Educación superior. Consultado el 22 de abril 2021. Disponible en: https://moodle.com/es/soluciones/educacionmas-alta/

Toledo, M. B., Correa Castillo, S., Valdés Montecinos, M., \& Hadweh Briceño, M. (2020). Modelo de gestión educativa para programas en modalidad virtual de aprendizaje. Revista de Ciencias Sociales, 26(2), 286-298.

MIRELES-MEDINA, Antonia, MOLINA-WONG, Ma. del Refugio, ÁBILAAGUILAR, Verenice and MOTA-GARCÍA, María Juana. Influence of digital technologies on higher education students in times of the Covid-19 pandemic and technologies on higher education students in times of the Covid-19 pandemic an the repercussions on their study habits. Journal of Information Technologies and Communications. 2021 
Organización Mundial de la Salud, (2020a). COVID-19: cronología de la actuación de la OMS. Consultado el 18 de abril 2021. Disponible en: https://www.who.int/es/news/item/27-04-2020who-timeline---covid-19.

Organización Mundial de la Salud, (2020b). Preguntas y respuestas sobre COVID-19 y temas de Salud relacionados. Disponible en: https://www.who.int/emergencies/diseases/nove 1-coronavirus-2019/question-and-answershub/q-a-detail/coronavirus-disease-covid-19

Reinoso Ayala, M. (mayo de 2020), "El papel de las TICs para apalancar la economía y el contacto Social ante el covid-19", [Internet], disponible en: https://www.telesemana.com/blog/2020/05/13/e 1-papel-de-las-tics-para-apalancar-la- economiay-el-contacto-social-ante-el-covid-19

Sampieri, R. H., Fernández Collado, C., \& Baptista Lucio, P. (2014). Metodología de la Investigación. México: Mc Graw Hill, Education.

Sánchez, C. S. (2002). Diccionario de las Ciencias de la Educación. 18va ed. México. ed. Aula Santillana.

SANZ, I., (2020), "Efectos de la crisis del coronavirus sobre la educación”, Magisterio. Disponible en: https://www.magisnet.com/2020/03/efectos-dela-crisis-del-coronavirus-sobre-la-educacion/.

Tecnológico Nacional de México | TecNM, (2021). Tecnologías Educativas: Herramientas Tecnológicas para CONTINUIDAD ACADÉMICA. Disponible en: https://www.tecnm.mx/?vista=TecNM_Virtual \&tecnm_virtual=Tecnologias

Torres, Á. (2004). La educación superior a distancia: entornos de aprendizaje en red. Guadalajara: Universidad Autónoma Metropolitana.

Sánchez, A., R., I. (2003). La educación a distancia. ACIMED, 11(1), 3-4. Recuperado en 20 de abril de 2021. Disponible en: http://scielo.sld.cu/scielo.php?script=sci_arttext \&pid=S1024-

94352003000100002\&lng=es\&tlng=pt.
SEP (2020a). Lineamientos de acción covid-19 instituciones públicas de educación superior. Secretaria de Educación Pública, 1-27. http://www.anuies.mx/recursos/pdf/LINEAMIE NTOS_COVID-19_IES_SES_VFINAL.pdf

SEP, (2020b). Respuestas de las Instituciones Públicas de Educación Superior en México para enfrentar la crisis del COVID-19. Anuies, 18. Disponible en: http://www.anuies.mx/media/docs/avisos/pdf/2 00417115709VF_ACCIONES_SES_COVID_1 9_ANUIES.pdf

UNESCO, (2020). Compromiso de las instituciones de educación superior con la comunidad. Respuesta Educativa de La UNESCO AL COVID-19 Notas Temáticas Del Sector de Educación, 10. https://unesdoc.unesco.org/ark:/48223/pf00003 74128_spa/PDF/374128spa.pdf.multi

UNESCO, (2020b). Distance learning solutions, UNESCO. Consultado el 20 abril 2021. Disponible en: https://en.unesco.org/covid19/educationrespons e/solutions.

UNESCO, (2020c). Interrupción educativa y respuesta al covid-19. Consultado el 15 de abril, 2021.

Disponible:

https://es.unesco.org/covid19/educationrespons e

UNESCO, (2021). La respuesta de la UNESCO al COVID-19. Consultado el 25 Abril 2021. Disponible en: https://es.unesco.org/covid19 